\title{
LITERARY LEARNING FOR TEENAGER INMATES IN INSTITUTE FOR CHILDREN SPECIAL REHABILITATION
}

\author{
Anwar Efendi*, Rachma Nurjanah \\ Universitas Negeri Yogyakarta, Indonesia \\ *e-mail: anwar@uny.ac.id
}

\begin{abstract}
Children who are afflicted with problems of the law must remain entitled to obtain services, guidance, education, protection, and fulfillment of their rights. This is directed to help children to prepare for their future life which is better and more dignified. The study is aimed at describing the nurture of children offenders, the running, and the benefits of literacy learning for inmates who receive rehabilitation treatment in the Institute for Children Special Rehabilitation (ICSR) of Class II B of Yogyakarta Province, Indonesia. The study is descriptive qualitative research involving 23 inmates and one instructor. Data are obtained from observations, interviews, and documents. Data analyses are done in three phases; namely selection, presentation, and conclusion. The findings are as follows. First, the rehabilitation phases in the ICSR are orientation, personality nurture, advanced nurture, and integration. Orientation and nurture phases are conducted in the ICSR, while integration is done outside the institute. Second, the literary learning activities are run informally taking the inmate conditions into consideration. Instructional materials consist of poetry writing, poetry musicalization, and basic exercises in drama staging. Third, literary learning gives benefits in character education, the betterment of social adaptation, and media for catharsis.
\end{abstract}

Keywords: literary learning, children inmates, juvenile delinquency, character building

\section{PEMBELAJARAN SASTRA BAGI ANAK PIDANA DI LEMBAGA PEMBINAAN KHUSUS ANAK}

\begin{abstract}
Abstrak: Anak yang berhadapan dengan hukum harus tetap memperoleh pelayanan, pembimbingan, pendidikan, perlindungan, dan pemenuhan hak-haknya. Hal itu bertujuan untuk menyiapkan kehidupan masa depan anak yang lebih baik dan bermartabat. Penelitian ini bertujuan mendeskripsikan pembinaan anak pidana, pelaksanaan dan manfaat pembelajaran sastra bagi anak pidana di Lembaga Pembinaan Khusus Anak (LPKA) Kelas II B Daerah Istimewa Yogyakarta. Penelitian ini merupakan jenis penelitian deskriptif kualitatif. Subjek penelitian adalah 23 anak pidana dan satu orang guru (pembina) kegiatan bersastra. Pengumpulan data menggunakan cara observasi, wawancara, dan dokumentasi. Analisis data dilakukan dengan tiga tahapan, yakni penyeleksian, penyajian data, dan penarikan simpulan. Hasil penelitian sebagai berikut. Pertama, tahapan pembinaan anak pidana di LPKA, yaitu pengenalan, pembinaan kepribadian, pembinaan lanjutan, dan program integrasi. Kegiatan pengenalan, pembinaan kepribadian, dan pembinaan lanjutan dilaksanakan di dalam LPKA, sedangkan program integrasi dilaksanakan di luar LPKA. Kedua, kegiatan pembelajaran sastra dilaksanakan secara informal dengan mempertimbangkan kondisi anak pidana. Materi pembelajaran sastra yaitu menulis puisi, musikalisasi puisi, dan latihan dasar bermain drama. Ketiga, pembelajaran sastra bermanfaat bagi pembentukan karakter, peningkatan adaptasi sosial, dan media katarsis.
\end{abstract}

Kata Kunci: pembelajaran sastra, anak pidana, kenakalan remaja, pembentukan karakter

\section{INTRODUCTION}

A lot of crimes happen these days and, ironically, many are committed by young adults. Data from the Indonesian Commission for Child Protection show that there is an increase in crimes committed by young adults. In 2011,
695 young adults were found to commit crimes while, in 2018, the number was 1,344 (Yusuf, Mufarida, Purnama, \& Rochim, 2019).

Crimes committed by young adults initially begin from common children delinquency. As time passes, common juvenile delinquency 
begins to transform to crimes. Such crimes can be so severe that some bring about death casualties. Young adult crimes can take the forms of student brawls, motorcycle convoys, thefts, narcotics, and looting (Unayah \& Sabarisman, 2015).

From the legal point of view, children who commit crimes are categorized as children who have a problem with the law. They are to be responsible for their actions in front of the law. The legal processes that deal with children criminals are contained in the System for Children Crime Tribunal (SCCT). Through the SCCT, children crime offenders are not put in jail but are rehabilitated to become better citizens (Eleanora \& Masri, 2018).

The teen age is a period where youngsters try to find their self-identities (Gunarsa, 2013). The teens will experience a process of transformation from being dependent on others to being independent. Teens also begin to take responsibilities of their behaviours (Muawanah, Suroso, \& Pratikto, 2012). In principles, the teen age is a period of growth in which teenagers develop into mature adults. It is for this reason that, in order to achieve normal growth and development, teenagers need education, nurturance, advocation, and protection for the best of their future (Blakemore, 2018).

The same treatment is expected to be given to teens who do things that have consequence with the law. They are entitled to get appropriate legal protection. The SCCT must be given wider interpretation (Kesuma, 2018) in the sense that legal processes must be directed not merely to punish, but to nurture and advocate. Another more important effort is for related parties to find roots of the problems in order to be able to tackle the causes for the criminal behaviours (Young, Greer, \& Church, 2017).

When coming to the domain of law, the processes of the sessions in the law court must also include consideration of the needs and rights of children. Restorative justice must be prioritized in that the legal processes must not be based mainly on punishing the children; the injured persons, the families, and other related parties must be involved in the resolving of justice (Kesuma, 2018). Restorative justice includes the involvement of various parties in order to erase the criminal stigma that may be suffered by the children and restore what they can do in the society (Cahyaningtyas, 2015).
After going through all the court sessions, the teen offenders are taken to the Institute for the Children Special Rehabilitation (ICSR). The rehabilitation processes are understood to mean as an attempt to respect the rights of children. Efforts are directed to the improvement of the life quality of the children in order to prepare for their future life.

The physical environment of the ICSR has the design and set up to suit the concepts of a child-friendly building. The general appearance does not reflect that it is a prison building. Rooms are arranged like classrooms with interesting decoration. No bars are used. In their stay in the ICSR, the jailed children are not shut in prison cells, but they are let free to do normal activities like doing sports, going to classes, and developing their talents and potentials.

One such ICSRs in the Province of Yogyakarta is ICSR Class II B located in Gunungkidul Regency. Generally, the programs and activities conducted in this ICSR refer to the existing rules and regulations that mainly put forwards nurture principles. In order to implement these principles, one of the interesting activities in the place is literature learning. Through intense literary activities, it is expected that the teen inmates will be able to experience changes in their attitudes, characters and bahaviours along a positive direction (Ellis, 2002).

It is expected that the activities of literary appreciation in the ICSR give impacts to the children's ways of thinking, behaving, distinguishing between rights and wrongs, and defining their ways of life. Literary values are able to guide persons, including these teen offenders, to love peace, softness and sensitivity of the heart, and sharpness of the mind (Nurgiyantoro \& Efendi, 2013). Literary activities will be able to help readers to more deeply understand, internalize, and practice actions in life. Literature is capable of softening manners, developing sensitivity towards life problems, and introducing value systems in children, both individually and collectively in social contexts (Weber, 2012).

In relation to child nurture, literature is believed to be more effective than psychology. Literary works have an advantage, in a psychological sense, as they display characters and become the medium for expressing a mental atmosphere. In addition, literature can bring 
readers to the psychological dimension that is closely related to life realities (Emir, 2016).

The present study is aimed at describing the process and benefits of nurturing children crime offender in the form literature learning in the ICRS Class II B of the Province of Yogyakarta. It is expected that literary activities can be done in other Class II B ICSRs in Indonesia so that the these children who have problems related to the law are able to continue developing their potentials for their future life.

\section{METHOD}

The study was set up in a descriptive qualitative research design. The research subjects were 23 teen inmates and one instructor participating in the literary activities in the Yogyakarta Province ICSR Class II B.

Data were obtained from documentation, interviews, and observations. From the documentation, descriptions were obtained of the inmates, interviews involved the inmates, teacher, and management to obtain information about the advantages of the literature learning, while observations were done on the conduct of the literary activities.

Data analyses were done in three phases: (1) selection, (2) presentation, and (3) conclusion. Obtained data were selected into patterns and categorized into groups in accordance with the research foci, namely: implementation and usefulness of the literary program. Presentation included description and narration about a short history of the ICSR and implementation and advantages of the literary activities. Conclusion was drawn concerning the benefits of the literary program for the psychological and social developments of the children crime offenders.
Data trustworthiness was obtained from the source and method techniques of triangulation. In the source triangulation, a second interview was done concerning a subject by respondents who knew the subject well. Responses by the teen inmates were crosschecked against information given by the management who tackled the subject's case. The teen inmates were placed in the ICSR through thorough identification and interrogation both by the police and the prison officers. Meanwhile, in the method triangulation, data were compared across the results of the documentation, interviews, and observations. Data resulting from the interviews were crosschecked against data resulting from the observations.

\section{FINDINGS AND DISCUSSION Findings}

The Institute for Children Special Rehabilitation of the Yogyakarta Province has the vision of becoming an agent of social rehabilitation activities that is pro-active, creative, and innovative by giving services, rehabilitation, education, and protection to children crime offenders. The vision is further specified in the missions: (a) elevate the levels of worship to God and piety to parents, (b) develop self-discipline and obedience to existing norms and rules of conduct, and (c) form creative vivacity and skills through the development of interests and talents.

These vision and missions become the guidelines of the ICSR in providing services and activities for the inmate rehabilitation. Duties and responsibilities of the ICSR are also contained in the Government Decree Number 31 Year 1999 about the nurturance and guidance of Children Crime Offender (RoI, 1999). Subsequently, the phases of inmate rehabilitation are presented in Table 1.

Table 1. Phase of Nurture of Children Crime Offender

\begin{tabular}{cll}
\hline No. & Phase & Core Activity \\
\hline $1 . \quad$ Initial & & Observing and studying personal identities \\
& Planning personality nurture program \\
& & Implementing personality nurture program \\
& & Evaluating personality nurture program \\
& & Planning continued nurture program \\
2. Advanced & Implementing continued nurture program \\
& & Evaluating continued nurture program \\
& Planning and implementing assimilation program \\
& & Planning integration program \\
3. Final & Implementing integration program \\
& & Conditioned acquittal \\
4. Integration & Interaction with family and society \\
\hline
\end{tabular}

Literary Learning for Teenager Inmatesin Institute for Children Special Rehabilitation 
Children with legal problems are classified into three categories: (a) inmate children, (b) state children, and (c) civil children. First, inmate children are those who, under the court decision, carry out the court sentence in the ICSR for the longest period of 18 years of age. Second, state children are those, under the court decision, given to the state to be placed and educated in the ICSR for the longest period of 18 years of age. Third, civil children are those, under the request of parents or guardians, obtain the court consent to be educated in the ICSR for the longest period of 18 years of age. State and civil children are sent back to parents and Institute for Social Welfare (IFSW), while inmate children are sent to ICSR (RoI, 1995).

In the study, there were 23 children housed in the Yogyakarta Province ICSR of the II B type. These were children and teenagers who received rehabilitation treatment in the ICSR were crime offenders who had finished their court processes and been verdicted to certain imprisonment. Data for these inmate children are presented in Table 2.
In an indirect manner, literary learning has actually been done since the ICSR was firstly established. In every national or religious holiday, the staging of literature was often held with the help of a literature teacher from outside. The ICSR management held a joint effort with the Office of Education of the Gunungkidul Regency to carry out such activities. One of the personnel was Sigit Purnomo who then initiated the learning of literature for the inmates of the ICSR.

Sigit Purnomo, alias Wage Dhaksinarga, is a social figure who gives due attention mental and psychological health. He owns a social institution, called Imaji Institute, that pays attention to suicide cases and other psychological problems in Gunungkidul Regency. $\mathrm{He}$ is a graduate of the Theatre Department of the Indonesian Arts University and the Psychology Department of Ahmad Dahlan University. This educational background has played an important role in his involvement in the literary learning for the inmates of the ICSR.

Table 2. Data of Teen Inmates in ICSR Class II B Yogyakarta Province

\begin{tabular}{lllll}
\hline No. & Classification & Detail & Number & Percentage (\%) \\
\hline 1. & Place origin & a. Yogyakarta & 9 & 39.1 \\
& & b. Sleman & 4 & 17.4 \\
& & c. Bantul & 1 & 4.3 \\
& & d. Gunungkidul & 5 & 21.8 \\
& & e. Kulonprogo & 2 & 8.7 \\
& & f. Magelang & 2 & 8.7 \\
2. & Age & a. 17 years & 12 & 52 \\
& & b. 16 years & 7 & 30.4 \\
& & c. 15 years & 4 & 17.4 \\
3. & Education & a. Senior High & 16 & 69.6 \\
& & b. Junior High & 7 & 30.4 \\
4. & Case & a. Brawl & 7 & 30.4 \\
& & b. Violence/killing & 5 & 21.8 \\
& & c. Sexual & 2 & 8.7 \\
& & d. Theft & 8 & 34.8 \\
& 5. & e. Narcotics & 1 & 4.3 \\
& Sentence & a. Five years & 5 & 21.8 \\
& & b. Four years & 2 & 8.7 \\
& c. Three years & 11 & 47.8 \\
& d. Two years & 1 & 4.3 \\
& & e. Less than 1 year & 4 & 17.4 \\
\hline
\end{tabular}


The learning activities are not yet documented in written forms; however, the plan and activities are in the lesson notes of the literature teacher. The literary activities include poetry reading and writing, poetic music creation, and basic practices in drama and theatre.

The lesson plan for the literary learning is presented in Table 3.

Although learning activities have been planned as such, they do not always run in accordance with the designed schedule. The literary learning program is informal in nature so that activities can change any time in accordance with the needs and interests of the inmate learners. In its basic principles, the objective of the program is not for the teens to be able to write poems or to be good at theatre acting, but it is more directed to character building. The literary activities are expected as a tool or medium for the inmates to build their personalities.

In the wider scheme, the literary learning program is one of the activities in giving helping treatments to the teen inmates in the ICSR. The estuary of all the literary activities is the need and benefit for the teens in order to prepare for future life to be better and more beneficial. Phases they experience during their stay in the ICSR can be come priceless lessons in their life stages. Benefits of the literary learning are presented in Table 4.

Tabel 3. Plan for Literary Activities in the ICSR

\begin{tabular}{|c|c|c|c|}
\hline No. & Learning & Material & Time \\
\hline 1. & $\begin{array}{l}\text { Inmates can } \\
\text { write poems }\end{array}$ & $\begin{array}{l}\text { a. Reading and introducing poetry forms } \\
\text { b. Understanding steps in poetry writing } \\
\text { c. Writing poems based on personal experiences } \\
\text { d. Editing written drafts of poems }\end{array}$ & $\begin{array}{l}\text { Monday } 2 \text { Hours } \\
\text { Tuesday } 2 \text { Hours }\end{array}$ \\
\hline 2. & $\begin{array}{l}\text { Inmates can } \\
\text { create poetry } \\
\text { musicalization }\end{array}$ & $\begin{array}{l}\text { a. Listening to poetry musicalization } \\
\text { b. Understanding types of poetry musicalization } \\
\text { c. Creating musicalization of poetry written by poets } \\
\text { d. Practicing poetry musicalization } \\
\text { e. Practicing poetry reading } \\
\text { f. Recording and discussing poetry music }\end{array}$ & Wednesday 2 Hours \\
\hline 3. & $\begin{array}{l}\text { Inmates can learn } \\
\text { the benefits of } \\
\text { drama rehearsal }\end{array}$ & $\begin{array}{l}\text { a. Introducing forms of drama staging } \\
\text { b. Introducing steps in preparing drama staging } \\
\text { c. Body management } \\
\text { d. Voice management } \\
\text { e. Feeling management } \\
\text { f. Thought management } \\
\text { g. Role play }\end{array}$ & $\begin{array}{l}\text { Thursday } 2 \text { Hours } \\
\text { Friday } 2 \text { Hours }\end{array}$ \\
\hline
\end{tabular}

Tabel 4. Benefits of the Literary Learning for the Teen Inmates

\begin{tabular}{cll}
\hline No. & Aspect & Detail \\
\hline 1. & Character Building & Developing personality and self-confidence \\
& & Growing joint-work awareness and respect to others \\
2. & Social Adaptation & Organizing self for change of mindset \\
& & Motivating self for change of behaviour \\
3. & Medium for Catharsis & Obtaining enjoyment and entertainment \\
& & Letting out thought and feeling burdens \\
\hline
\end{tabular}




\section{Discussion}

\section{Nurture of the Teen Inmates of ICSR}

Treatment of the nurture of the ICSR inmates is carried out in four phases; namely (a) initial, (b) advanced, (c) final, and (d) integration. These phases are described as follows.

First, in the initial phase, treatment commences from the day an inmate is sentenced for imprisonment up to the one third of the verdicted period. The process begins with administration and orientation; i.e. the entrance date, verdict documents, length of imprisonment, and end of imprisonment. The results are used for the making of the ensuing nurture programs.

Second, in the advanced phase, the nurture treatment is divided into two periods; namely the first advanced period and the second. The first advanced period begins from the end of the initial phase up to the half of the verdict length. The second advanced period begins from the end of the first up to the two-third of the verdict length.

Third, in the final phase, nurture treatment lasts from the end of the advanced phase to the end of the verdict length. The inmates are prepared physically and mentally to adapt to the environment of the family and society at large.

Fourth, the integration phase begins after inmates have finished their two-third of the verdict length and lasts for at least nine months. At this time, inmates can be given conditioned acquittal. They are already back in the midst of the family and society. When the conditioned acquittal is up, inmates must go back to the ICSR to process the documents for the acquittal (RoI, 1999).

These phases of rehabilitation reflect the process of moving towards maturity. In the practice, the treatment of the initial and advanced phases is done inside the rehabilitation centre while the final phase is done outside.

An emphasized principle in the rehabilitation processes is given to the presence and existence of the teenagers. Nurture processes are thus prioritizing the rights of the young adults. One effort that is always kept to be done is the finding of the roots of the problems and prevention of the emergence of teen delinquencies.

Children crimes usually begin from these juvenile delinquencies. In the development, mischievous bevahiours change qualities and become criminal actions. One of the influencing is the massive infringement of the social and technological media on these youngsters. Overuse of digital media has caused the teenagers to lose happiness and social interaction (Twenge, 2019).

The young adults experience changes from childhood to adulthood, at 12 to 21 years of age. This is marked physical, mental, social, and emotional maturity growths (Knol, Wienberg, Speekbrink, \& Blakemore, 2015). In this period, children experience significant changes in almost all facets of their life. These changes include the biological functions, cognitive abilities, social relations, and peer relations (Bailen, Green, \& Thompson, 2018).

It is these changes that also become one of the causing sources of delinquencies. The mischievous behaviours bring about detrimental consequences on self and others (Sabandar, 2017). Delinquencies range widely from behaviours that are not acceptable to the community to actions that are criminal. They can come up in the forms of crimes, persistent antisocial behaviours, or rebellions to parents or authorities. In the legal perspectives, these delinquencies tend to lead to law breaking by under-age children.

Treatment of the teen inmates in the ICSR must always consider the essential natures of the young adults as described in the foregoing discussion. Nurture activities must involve the participation of all parties; from parents, school teachers, community leaders, to peer. An important vision is the prevention that criminal actions by these young adults can be anticipated early.

\section{The Literary Learning Activities in the ICSR}

In this study, the literary learning program conducted in the Class II B ICSR in Yogyakarta Province belongs to the category of informal education. Informal education is one which is done independently, consciously and responsibly, by way of the family and community education systems. It can be done in any place, with no specific requirements and no leveling, the program is not designed in a formal way, the material is based on the learners' needs, there is no grading and no exam, and the providing body is flexible in its facilitation of the learning program (RoI, 2003). 
The literary learning program emphasizes more on literary appreciation or experience. From this program, the teen inmates are expected to have enlightenment and, at the same time, development of their interests and talents. This is in line with the Horatian classic adagium that literature simultaneously has dulcet and utilitarian functions (Suwondo, 2017).

First, the activity was writing poems. Initially, the instructor was not able to give explanation as no specific method was used in the learning process, unlike those done in schools. However, after an explanation on the steps of the learning activity, it was identified that the method was similar to those of the literature workshop.

The workshop method is one that emphasizes creative literary activities guided directly by an artist or a poet. Activities are directed to be acquainted with, understand, and appreciate literary works. Literature workshop is intended to help learners develop their creativities, especially in poem writing by way of constructing and deconstructing (Abidin, 2005).

In the initial phase, participants were assigned to write a poem as far as they were able to (Syarifuddin, 2016). The poem was then discussed together with the poet and instructor. Poems that were lacking in quality and sentences that were not logical were revised. This process was done repeatedly until satisfaction was reached in accordance with the learners' ability levels of understanding. In the final phase, the instructor selected some poems that are considered well-constructed to be subjected to final discussion and, later, nominated to be included in an anthology. Examples of poetry are presented in the appendix.

Second, the activity was musicalization of poetry. No specific method was used in the learning sessions. In the initial phases, an audio medium, in the form of a documentary of a poetry musicalization show, was used to make the inmates familiar with the subject and have some thoughts about poetry musicalization. These poetry musicalization shows were the ones that had been performed by the instructor or poet.

In the ensuing activities, the instructor explained the meaning of poetry musicalization, kinds of poetry musicalization, aspects to be considered in the making of poetry musicalization, steps in the making of poetry musicalization, and the process in the staging of poetry musicalization. The activities were mostly discussions followed by questions and answers. Most participants were usually very enthusiastic with what they were doing.

The teen inmates were given three weeks to compose poetry music pieces from given poetry anthologies. In the end, two groups were formed to finalize their work. In the final phases, the instructor gave comments, feedbacks, and explanation of the creative processes that they had done (Indriati \& Haryadi, 2014).

Poetry musicalization is highly advantageous for the development of the inmates' interests and talents. First, it can stimulate their interest in poetry as it is presented in music which most of them like. Second, it gives refreshment to them in that the learning activities are not monotonous. Third, it gives the learners opportunities to be directly acquitted with literary work. Fourth, it gives cognitive, affective, psychomotor, and emotive stimulation to the learners (Ari, 2008).

The choice of poems from the Blues for Bonnie anthology was surprising and interesting to find. One of the poems for musicalization was "Testimonies of the Year 1967" by WS Rendra. This choice for poetry musicalization epitomized the inmates' thoughts and characters.

When they were asked about the poem, "Testimonies of the Year 1967", the teen inmates were able to give answers in simple ways. They showed their understanding that the poem was about political events in Indonesia in that era. The making of the music for "Testimonies of Year 1967" was profoundly finished. This shows that the inmates were able to process information from poetry texts. As readers, they were capable of not only understanding new knowledge, but also processing information (Alderson, 2000).

Third, the activity was basic exercise in drama. The method used in the activity referred to the understanding of drama preparation of an artist (Stanislavsky, 2007). Elements of drama basic exercises given in the learning activities included (a) body movement, (b) vocal management, (c) emotion management, (d) thought management, and (e) role practices.

First, for body movement, participants were trained in strength, elasticity, and stamina 
of the body and coordination of movement for theatre staging. The body movement exercise included two aspects: mimics and gestures. Mimics were facial movements showing the condition, nature, and characterization of the character being played. For this, facial gymnastics were done to perform various emotional expressions. Participants were trained to express various emotions such as smiling, laughing, staring, gaping, winking, lip twisting, and getting startled or shocked.

Gestures were all other body movements than the face. Gestures were also used to show the condition, nature, and characterization of the character. Gesture training included warmingups (jog, push up, sit up), joint stretching, and movements of everyday life activities. Gesture exercises could be modified to suit the needs and conditions of the artists (Hamzah, 2000).

Second, for vocal management, exercises were directed to represent thoughts and feelings carried in within the dialogues among players on the stage (Tambayong, 2000). Voice and pronunciation had the functions of (a) transmitting words to the audience, (b) giving senses and emphases on certain words, (c) giving clues about the feelings and characters of the players (age, social status, occupation, etc.), and (d) expressing emotions emotion (anger, joy, despair, anxiety, and others).

Vocal management exercises consisted of two activities: breathing and pronunciation. Exercises in breathing included chest breathing, belly breathing, and diaphragm breathing. Chest breathing was done by inhaling air into the lungs indicated by the raising of the shoulders and protruding of the chest. Belly breathing was done by inhaling air into the stomach indicated by the expansion of the stomach. Diaphragm breathing was done by inhaling air into the diaphragm, the part between the chest and stomach. Meanwhile, pronunciation exercises included two aspects: pronunciation and stresses. Pronunciation of vocals, consonants, and combination among vocals and consonants should be clear and distinct. Stresses, tempo, and volume of the sounds must also be matched with the message being transmitted. Short and long and harsh and soft voices were also important elements of the expressions of the artists.

Third, for emotion management, participants were trained in the abilities to be sensitive and focused on the role character. An artist was expected to be able to focus on his or her character role, be sensitive on what happened around, and responsive towards other players. Emotion management could be done by meditation. In meditating, participants were asked to contemplate on self, parents, other people around, and things and problems they had been having so far. They were asked to try to get rid of negative things and seek positive things. Emotion management enabled participants to question their identities by increasing their selfawareness (Aras, 2015).

Fourth, for thought management, participants were trained to improve their abilities to act as the assigned roles, even if the roles were contradictive to what they were. For example, if an actor was cast as a mad person, he or she had to be able to show the behaviours and actions that mad persons did. This required the smartness of the person to be able to act as he or she was assigned to. Role playing needed the mastery of the psychology and understanding of the character. Thought management exercises included concentration practice, paying all feelings and thoughts on the role play. This was done by exercising all the five senses (Hamzah, 2000).

Fifth, for role practices, participants were trained to act on the bases of imitative actions. Various emulations were done by imitating physical movements such the walking of a dwarf. Psychological movements were represented by the aids of gestures and facial expressions such as uses of breath, voice, and gestures to simulate a weeping person (Waluyo, 2001).

\section{Benefits of Literary Learning for Teen Inmates}

Literature can give an impact on one's ways of thinking about life, of acting whether good or bad, and of choosing which is right or wrong. Literature can also help readers to understand life, internalize living, and show directions. It is commonly accepted that literature has the potentials to make the readers live a more humanitarian life. With presumed advantages, the existence of literature is needed by the society, including teenagers who occupy children rehabilitation institutes.

First, literary learning functions to build characters. Literary works are art expressions that use language as the medium of communication. 
Since literature is directly related to aspects of human life, literary works can be regarded as historical facts about human life with language as the medium of expression. As a part of historical facts about human life, literature is a manifestation of human thoughts. For these reasons, it is often stated that literary works play an important role in a nation character building (Almerico, 2014).

Literary learning can be aimed at softening one's manners, developing one's sensitivities towards life problems, as well as teaching one value norms, either individually or in a wider social context (Mar, 2018). In this case, learning of poetry writing, for example, can become a medium of character building for children inmates of rehabilitation centres (Wulandari, 2015). Poems written by these children inmates can be further studied to look at character forms that are reflected in them.

\begin{abstract}
"Just look at the poems they wrote, we can find many characters there that are reflected in their writing. Writing is a self-mirror; so there should be children's characters that are indirectly represented in their writing that we can see." (Quotation from interview with Instructor)
\end{abstract}

Characters in a story, that are presented in various characterizations, may stimulate readers to contemplate which characters should be accepted and which rejected. In works of literature, characters are narrated just like real people with three dimensions: physiological, psychological, and sociological. From these three dimensions, readers can scrutinize and understand the characters and their characterizations (Manuaba, 2009).

Character-building processes through literature are sought to be more natural and and continuous. Values that are contained in literary works can be used as effective materials or instances in character building. Readers experience for themselves these character values in their interaction with the texts in an enjoyable environment. These processes help memory and awareness strongly attached in their inside. Values and meanings that are considered to be good and beneficial become the "ownership" of the readers (Mar, Oatley, \& Peterson, 2009).
Interaction between readers and the literary work is a process of awareness building and value internalization that is "quiet" and "solitary". Readers are given the opportunities to interact, have enjoyment, and argue with themselves in the process of understanding and giving values to literary works. The ultimate route is for the readers to formulate responses whether to "accept" or "reject" the values in the literary works (Mar, Oatley, Djikic, \& Mullin, 2011).

In his study about King Midas in the movie film Avengers: The Infinity War, Muzaki (2018) describes how moral values are more valuable than authority power. King Midas' might and power turn out to give him confusion as he is being abandoned by his community. It is, therefore, true that a person who holds high position in a community must highly hold up humanitarian values. Such condition is the one that children inmates carry along when they rehabilitated and return to live with the society.

Second, literature functions as a medium for social adaptation. Literature has a part in the processes of social change. Emmanuel (2014) states that literature plays a role in creating better thoughts. In line with this, Sarwono, Rahayu, \& Purwadi (2017) state that literature, including oral literary forms, represents knowledge of cultures and practice of social interactions in a community.

In a wider perspective, there is correlation one's between reading skills and one's understanding of social interactions (Kozak \& Recchia, 2019). It is, therefore, true that choice of reading materials must be given a special attention in order to give benefits to the readers, especially in relation to developing social knowledge and understanding. In the context of children rehabilitation inmates, activities of reading and literary appreciation can be used as a way to develop sympathy and empathy in the children inmates so that they will be able to adapt to their social environments.

Literature can also function to help change thought and behaviour patterns and social structures of the community (Sumara, Humaedi, \& Santoso, 2017). Art and literature can carry out their adaptive functions; namely organizing, motivating, and behavior changing (Carroll, 2006). 
In this context, literature has the potentials to influence children inmates to move towards better behaviours. For instance, during the emotional management exercises, many teen inmates weep. It seems that what the instructor narrates to them using poetic language is able to move and soften their heart. In the emotion management sessions, participants are carried away by feelings that have long been buried in their inside. They are led to enter to the imaginative world.

The essence of drama is human conflict (Pratiwi \& Siswiyanti, 2014). It is by this reason that the activities of appreciating and understanding drama resemble attempts to approach, recognize, understand, appreciate, and critique various human characters in various dimensions (Dewojati, 2010). Drama practice is able to give effective satisfaction to trainees, most specifically rehabilitation inmates. The children inmates are able to use spoken language, develop personalities, learn to work in cooperation with others, and find truth (Sumaryadi, 2006). In addition, they are also able to develop their abilities in presenting thoughts and expressing feelings.

\begin{abstract}
"Rehearsals of drama or theatre are not solely for staging purposes, but also for rehabilitation purposes of inmates. Those children need to be guided and diagnosed for therapy; drama basic exercises will be able to help: therapy which does not like one. The children then are guided to experience emotion management and feel their own body, arms, legs, eyes; all their body parts. This is because the drama program is not just staging. It is also directed to build their characters to the point they can be induced with positive sentences" (Quotation from interview with Instructor)
\end{abstract}

In the world of the theatre, emotion management is used to deepen understanding on the characterization of the characters of the play. In other words, emotion management is used as a medium to exercise mental sensitivity. Inmates who do not admit themistakes will stay hardheaded to deny their criminal actions. By way of emotion management, children are reminded of many things they are impacted to, the crimes they have committed, their wrongs to their parents, and so on. Participants who have gone with the realm of emotion management and have developed their imaginations will have a space in their thought for indoctrination. It is at this phase that positive motivations are induced and advices and new thought patterns are formed (Zickfeld, Schubert, \& Seibt, 2019).

Third, literary activities function as a medium for catharsis. Catharsis can be given a meaning of mental cleanser. Aristotle states that one function of literature is a cathartic medium or mental cleanser for the poet (Solbakk, 2006). For readers, after they read, the will feel that their thoughts and feelings are open since they have obtained experience and entertainment.

For the children inmates, it is expected that writing will have a positive impact on their psychological development. After having produced a literary work in the form of a poem, they will experience mental cleansing and feel free and open for, at least, they have let out the burdens in their feelings and thoughts. The children inmates have been given the freedom to express their mental and thought conditions they are experiencing. The resulting poems are expressions that emanate from their life contexts (Khattak, Mehnaz, \& Khattak, 2011).
“Sister, I can't write a poem (weeping). I'm not worth of it. It's hard for me to open it. I can't write. I feel ashamed, sister. I've wronged my Mom and Dad." (Quotation from interview with an inmate)

The instructor asked the inmate to write down all that have bothered his mind. She emphasized that he did not have to worry about the rules of poetry writing. She just told him to write everything he wanted to say to his parents. She persuaded him to believe that, by writing, he would feel relieved. She persuaded him to write down whatever he had wanted to say, which he had not had the chance to do it.

\footnotetext{
"No need to bother about how to write poetry; just write down what you want to say, that you won't tell us. After you write, you then tell us all about it; we'll look together, shall we?" (Quotation from interview with Instructor)
}

The inmate, who initially kept silent, 
became gradually open himself, both to the instructor and to his friends. When writing the poem, he wept, his hands shaking; he did not have the strength to express his sadness to himself for having made his parents disappointed. When the instructor asked him how he felt after writing, he replied that he felt relieved.

'Here's my poem; it's okay, all right? That's what I usually can do. I feel relieved after writing this. I feel guilty to my parents, 'specially Mom (weeping). I've made her feel ashamed. She must be so. I miss her. When I'm out, I'll change, I'll made Mom happy."

(Quotation from interview with inmate)

The literary learning processes can be used expressively by way of writing poems, musicalizing poems, and rehearsing drama. It is interesting to note that children inmates have different stories and backgrounds that influence their attitudes and behaviours.

Literary activities can become one of the psychological therapeutic methods for children rehabilitation inmates. In the environment where children inmates find it hard to express their thoughts and feelings to the instructor or management, the literary activities can become an alternative solution. As has been pronounced by Mar \& Otley (2008), literature can facilitate one in understanding those who are different.

In essence, literary work is a result of individual expressions of the artist. It can be underlined that literary work can show the feelings and thoughts of the poet. Literary work can build up motivation to express self and reveal mental disturbances (Irene, 2015).

\section{CONCLUSION}

Based on the results and discussion of the study, conclusion can be drawn as follows. First, children who have problems with the law must be given services, guidance, education, protection, and fulfillment of their rights. This has the purpose of helping these children to prepare for a better and dignified life. One important aspect is for related parties to find the roots of the problems and prevent juvenile delinquency to occur. Nurturance efforts should be more prioritized than imprisonment or punishment. The nurturance phases in the treatment of children inmates in the ICSR are orientation, personality development, advanced treatment, and integration. The first three phases are carried out in the rehabilitation institute while the last is done outside.

Second, the literary learning program conducted in the Class II B of ICSR of Yogyakarta Province is informal in nature. The learning is directed more to the activities of literary experience rather than literary knowledge. Instructional materials and schedules are designed and implemented in flexible ways to match with the conditions of the inmates. The materials included poetry writing, musicalization of poetry, and basic exercises in drama staging. The workshop approach is used for the learning activities since it is regarded as the most suitable.

Third, for the children inmates, the literary activities can become media for character building, social adaptation, and cathartic processes. Literary activities can develop personalities, self-confidence, and awareness to cooperate with and respect others. In terms of basic drama exercises, literary activities can help participants to organize and motivate self to make changes in thought and behaviour patterns. The children inmates with their burdens in feelings, thoughts, and other mental enrages are able to express them by way of the literary activities. It is through these processes that they feel their emotive, cognitive, and psychological conditions are clean and clear in order to society members who are better and more dignified.

\section{ACKNOWLEDGEMENTS}

Deep gratitude is devoted to the Management of the Class II B ICSR of Yogyakarta Province and Mr. Sigit Purnomo, Instructor of the literary learning program. Affectionate thankfulness is specially reserved for the great and talented teenagers who, at the present time, are undergoing rehabilitation processes at the ICSR.

\section{REFERENCES}

Abidin, Y. (2005). Pembelajaran bahasa berbasis pendidikan karakter. Bandung, Indonesia: Refika Aditama.

Alderson, J. C. (2000). Assesing reading. New York, NY: Cambridge University Press. 
Almerico, G. M. (2014). Building character through literacy with children's literature. Research in Higher Educational Journal, 26(3), 1-10.

Ari, KPIN. (2008). Musikalisasi puisi tuntunan dan pembelajaran. Yogyakarta, Indonesia: Hikayat Publishing.

Aras, G. (2015). Personality and individual differences: literature in psychologypsychology in literature. Procedia Social and Behavioral Scinence, 185(2015), 250257. doi:10.1016/j.sbspro.2015.03.452.

Bailen, N. H., Green, L. M., \& Thompson, R. J. (2018). Understanding emotion in adolescents: A review of emotional frequency, intensity, instability, and clarity. Emotion Review, 11(1), 63-73. doi:10.1177/1754073918768878.

Blakemore, S. J. (2018). Avoiding social risk in adolescence. Perspective on Psychological Science, 27(2), 116-122. doi:10.1177/0963721417738144.

Cahyaningtyas, I. (2015). Pembinaan anak pidana di lembaga pembinaan anak khusus anak dalam perspektif restorative justice. Jurnal Notarius, 8(2), 342-353. doi:10.14710/nts.v8i2.10355.

Carroll, J. (2006). The human revolution and the adaptive function of literature. Philosophy and Literature, 30(1), 33-49. doi:10.1353/ phl.2006.0005.

Dewojati, C. (2010). Drama, sejarah, teori, dan penerapannya. Yogyakarta, Indonesia: Gadjah Mada University Press.

Eleanora, F. N., \& Masri, E. (2018). Pembinaan khusus anak menurut sistem peradilan anak. Jurnal Kajian Ilmiah, 18(3), 215230.

Ellis, D. (Ed.). (2002). Developing chararter through literature: A Teachers resoaurces book. Bloomington: Indiana University Press.
Emir, B. C.. (2016). Literature and psychology in the context of the interaction of social sciences. Journal of Humanities and Social Sciences, 19(4), 49-55.

Emmanuel,A. T. (2014). Literature an instrument of change in schools and the society. International Journal of Education (IJE), 2(3), 9-16.

Gunarsa, S. D. (2003). Psikologi remaja. Jakarta, Indonesia: Gunung Mulia.

Hamzah, A. (2000). Pengantar bermain drama. Bandung, Indonesia: CV Rosda Karya.

Indriati, D. A. \& Haryadi, H. (2014). Peningkatan apresiasi puisi dalam pembelajaran puisi dengan media musik pada siswa kelas XII SMA Negeri 11 Yogyakarta. LingTera, l(2), 156-167. doi:10.21831/1t.v1i2.2593.

Irene, K. V. (2015). The use of literature in the language classroom: methods and aims. International Journal of Information and Education Technology, 5(1), 74-79. doi:10.7763/IJIET.2015.V5.479.

Kesuma, S. (2018, February 7). Anak berhadapan dengan hukum. Negara Hukum. Retrieved from http://www.negarahukum.com.

Khattak, M. I., Mehnaz, M., \& Khattak, M. A. (2012). The role of stylistics in interpreting literature. City University Research Journal, 2(1), 97-102.

Knol, L. J., Wienberg, L. M., Speekenbrink, M., \& Blakemore, S. J. (2015). Social influence on risk perception during adolescence. Psychological Science, 26(5), 583-592. doi:10.1177/0956797615569578.

Kozak, S. \& Rechia, H. (2019). Reading and the development of social understanding: Implications for the literacy classroom. Reading Teacher, 72(5), 569-577. doi:10.1002/trtr.1760.

Manuaba, M. (2009). Persepsi pengarang tentang masyarakat: kajian tentang 
cerpen-cerpen karya pengarang Bali dalam perspektif sosio fenomenologis Bergerian. Yogyakarta, Indonesia: Logung Pustaka.

Mar, R. A. \& Oatley, K. (2008). The function of fiction is the abstraction and simulation of social experience. Perspective on Psychological Science, 3(3), 173-192. doi:10.1111/j.1745-6924.2008.00073.x.

Mar, R. A., Oatley, K., \& Peterson, J. B. (2009). Exploring the link between reading fiction and emphaty: Ruling out individual differences and examining outcomes. Communication, 34(1), 407-428. doi:10.1515/COMM.2009.025.

Mar, R. A., Oatley, K., Djikic, M., \& Mullin, J. (2011). Emotion and narrative fiction: Interactive influence before, during, and after reading. Cognitioan \& Emotion, 25(5), 818-833. doi:10.1080/02699931.2 010.515151 .

Mar. R. A. (2018). Stoires and the promotion of social cognition. Current Directions in Psychological Science, 27(4), 257-262. doi:10.1177/0963721417749654.

Muawanah, L. B., Suroso, S., \& Pratikto, H. (2012). Kematangan emosi, konsep diri, dan kenakalan remaja. Persona: Jurnal Psikologi Indonesia, 1(1), 6-14.

Muzaki, F. I. (2018). Prosocial behavior character of Thanos in the film Avengers of Infinity Wars. Litera, Jurnal Penelitian Bahasa, Sastra, dan Pengajarannya, 17(3), 336348. doi:10.21831/1tr.v17i3.20186.

Nurgiyantoro, B. \& Efendi, A. (2013). Prioritas penentuan nilai pendidikan karakter dalam pembelajaran sastra remaja. Jurnal Cakrawala Pendidikan, 32(3), 382-393. doi:10.21831/cp.v3i3.1626.

Pratiwi, Y. \& Siswiyanti, F. (2014). Teori drama dan pembelajarannya. Yogyakarta, Indonesia: Ombak (anggota IKAPI).
RoI, Law 1995 No. 12, Correctional Institution.

RoI, Government Regulations 1999 No. 31, Founding and Guidance of Prisoners.

RoI, Law 2003 No. 20, National Education System.

Sabandar, S. (2017, March 16). Daftar panjang aksi kekerasan klitih di Yogyakarta. Liputan 6. Retrieved from https://www. liputan6.com.

Sarwono, S., Rahayu, N., \& Purwadi, A. J. (2017). Rekontekstualisasi praktik sosial Merejung dalam naskah Ulu pada kelompok etnik Serawai Bengkulu. Litera Jurnal Penelitian Bahasa, Sastra, dan Pengajarannya. 16(2), 295-308. doi:10.21831/ltr.v16i2.15607.

Solbakk, J. H. (2006). Chatarsis and moral therapy II: An Aristotelian account. Medicine, Health Care, and Philosophy, 9(2), 141-153. doi:10.1007/s11019-0058319-1.

Stanislavsky, K. (2007). An actor preapers. (Trans. by A. Sani). Jakarta, Indonesia: PT. Bastela Indah Prinindo.

Sumara, D., Humaedi, S., \& Santoso, M. B. (2017). Kenakalan remaja dan penanganannya. Jurnal Penelitian dan Pengabdian pada Masyarakat, 4(2), 129139. doi:10.24198/jppm.v4i2.14393.

Sumaryadi, S. (2006). Pelaksanaan pembelajaran seni drama sejak usia dini. Jurnal Imaji, 4(1), 61-73. doi:10.21831/imaji. v4i1.6702.

Suwondo, T. (2017). Sastra dan pendidikan. Majalah Candra (Disdikpora DIY), 47(3), 7-8. doi:10.5281/zenodo.1303374.

Syarifuddin, S. (2016). Mengajarkan membaca dan menulis puisi di sekolah dasar. Jurnal Ilmiah Guru Caraka Olah Pikir Edukatif (COPE), 20(1), 31-40. 
Tambayong, J. (2000). Dramaturgi. Bandung, Indonesia: Pustaka Prima.

Twenge, J. H. (2919). More time on technology, less happiness? Associations between digital-media use and psychological well-being. Current Directions in Psychological Science, 28(4), 372-379. doi:10.1177/0963721419838244.

Unayah, N. \& Sabarisman, M. (2015). Fenomena kenakalan remaja dan kriminalitas. Sosia Informa, 1(2), 122-140. doi:10.33007/inf. v1i2.142.

Waluyo, H. J. (2001). Drama teori dan pengajarannya. Yogyakata, Indonesia: Hanidita Graha Widya.

Weber, H. A. (2012). Literature as a social tool: Education and cohesion or class domination? Inquries Journal Social Sciences, Arts, \& Humanities, 4(1), 1-6.

Wulandari, R. A. (2015). Sastra dalam pembentukan karakter siswa. Jurnal Edukasi Kultura, 2(2), 63-73. doi:10.24114/kultura.v1i2.5181.

Young, S., Greer, B., \& Church, R. (2017). Juvenile delinquency, welfare, justice, and therapeutic interventions: a global perspective. BJPsych Bulletin, 41(2), 2129. doi:10.1192/pb.bp.115.052274.

Yusuf, Y., Mufarida, B., Purnama, R. R., \& Rochim, A. (2019, March 14). Tindak kriminalitas anak sangat memprihatinkan. Koran Sindo. Retrieved from https:// nasional.sindonews.com.

Zickfeld, J. H., Schubert, T. W., \& Seibt, B. (2019). Moving through the literature: What is the emotion often denoted being moved? Emotion Reviewe, 11(2), 123139. doi:10.1177/1754073918820126.
Appendix: Examples of Poetry Written by Teenager Inmates

\section{Malam}

Karya DDW

Matahari melangsungkan kepulangannya

Dan berganti tugas dengan bulan

Mereka terangi belahan dunia

Yang menghidupi belantara manusia

Angin berhembus pelan

Menunjuk bagian ingatan dan kenangan

Di mana aku hanya bisa menatap diam

Pada langit yang begitu kelam

Itulah senja menuju malam

Waktu di mana aku pulang

Dan harus merindukan

\section{Sesal}

oleh NAS

Bosan aku menunggu

Hari-hari terasa lama berlalu

Hari demi hari kuhitung

Menanti hari kebebasanku

Jenuh terasa di hati

Rindu orang-orang yang kukasihi

Doa kupanjatkan setiap hari

Agar cepat semua ini kulalui

Sesal di dalam hati

Tiada henti kuratapi

Mengingat kejadian yang tak terlupakan

Sudah terjadi, mau diapakan

Syukur semua ini terjadi

Merubah hidup menjadi lebih berarti

Sungguh perjalanan yang bermakna

Membentuk diri untuk bekal masa depan 
Terlanjur

Karya MGRT

Hidup itu misteri

Masa lalu kembali menjegal kita

Padahal kita selalu mengejar masa depan

Lalu bagaimana dengan kehidupan sekarang

Aku tak pernah menyangka

Hidup di jeruji besi

Jiwaku selalu berontak ingin pergi dari sini

Tapi katahati selalu menang untuk mempengaruhi

Aku juga tak pernah membayangkan

Jika aku pulang dari tempat ini

Aku hendak berbuat apa

Sedang masa lalu terlanjur kelam

\section{Satu Tahun di Jeruji}

oleh AA

Rasa kecewa yang mendalam

Perasaan sedih yang makin menjadi

Merasuki tubuhku seketika

Tetesan air mata

Kaki mulai gemetar

Keringat bercucuran

Satu tahun akan ku lalui

Jauh dari orang tua

Sedih rasanya

Ini akibat dari kesalahanku

Aku berjanji kelak nanti

Waktu yang akan datang

Akan kujadikan waktu yang baik

Tak akan kuulangi kesalahan yang sama

Hari lalu telah berlalu

Hari esok masih misteri

Kujadikan pengalaman hari ini

Tombak untuk waktu mendatang kelak

\section{Maafkan Aku \\ Karya FAPWN}

Aku telah mengecewakanmu

Sudah banyak aku membuatmu menangis

Dari kecil sampai sebesar ini

Rasanya belum pernah aku membahagiakanmu

Yang ada hanya perbuatan yang menjadikanmu

khawatir, resah dan takut

Teringat di saat kau menasehatiku

Akupun mengacuhkanmu dan membentakmu

Pun dengan penuh kasih sayang

Kau selalu memaafkanku

Terkadang kau sampai harus menahan malu

Karena ulah dan tingkah lakuku

Cacian makian hinaan terhadapku

Selalu menjadi bahan untuk menyalahkanmu

Tapi kau tak pernah mengeluh sedikitpun

Dan tetap menyayangiku merawatku menjagaku

Betapa besarnya kesabaranmu menghadapiku

Maafkan aku orang tuaku

\section{Jangan Jatuh ke Lubang yang Sama Karya FAPWN}

Walau nasi sudah jadi bubur

Tapi jadilah bubur sungsum

Meski masa muda sudah hancur

Yakinlah untuk menuju masa depan masih

banyak jalur

Tuhan tidak pernah tidur

Kita harus tetap selalu bersyukur

Masih bayak jalur

Untuk menuju kehidupan yang lebih makmur

Percayalah ini hanya sebuah teguran

Jangan jadikan penyesalan

Langkahkan kaki ke depan

Raihlah impian dan kebahagiaan 